\title{
İngilizce Öğretmenlerinin Bilgisayar Destekli DynEd İngilizce Öğretim Yazılımı Hakkındaki Görüşleri
}

\author{
DOI: 10.26466/opus.670073
}

\author{
Bayram Gökbulut* \\ * Dr. Öğretim Üyesi, Bülent Ecevit Üniversitesi, Eğitim Bilimleri Fakültesi, Zonguldak/Türkiye \\ E-Posta: bayramgokbulut@hotmail.com \\ ORCID: $\underline{0000-0002-7218-5900}$

\section{$\ddot{O} z$}

Teknolojinin etkisi ile globalleşen dünyada insanlara bir yabancı dil bilmesi yetmemekte, birden fazla yabancı dil öğrenme ihtiyacı ortaya çıkmaktadır. Teknolojinin ortak dili ve evrensel bir dil haline gelmiş İngilizce, herkes tarafindan bilinmesi gereken bir dil haline gelmiştir. Milli Ĕ̆gitim Bakanlığı İngilizce dil eğitimine destek olması amacıyla DynEd programını ortaokul ve liselerde uygulamaktadır. Yapılan bu çalışma ile 2008 yılından beri uygulanan DynEd İngilizce dil eğitim yazılımının faydaları ya da uygulamada yaşanan sorunların ortaya konulması amaçlanmıştır. Bu amaç doğrultusunda 6 ortaokul ve 6 lisede görev yapan toplam 12 Ingilizce öğretmeni ile nitel bir çalışma yürütülmüştür. Yüz yüze görüşme ile gerçekleştirilen çalışmada veriler, yarı yapılandırılmış görüşme formu ile toplanmıştır. Verilerin analizinde içerik analizi yöntemi kullanılmıştır. Öğretmenler, DynEd uygulamalarında teknolojik alt yapı eksikliklerinin bulunduğunu, akıllı telefon uygulamalarında işletim sisteminden kaynakl sorunlar nedeniyle bazı telefonlara yüklenemene problemlerinin yaşandığını dile getirmişlerdir. Öğretmenler, Ingilizce dil eğitiminde yaşanan sorunların çözümünde DynEd'in tek başına çözüm olamayacağı, sadece dil eğitimine destek olabileceği görüşünü belirtmişlerdir.

Anahtar Kelimeler: İngilizce dil eğitimi, bilgisayar destekli eğitim, öğretmen ve öğrenci teknolojik yeterlilikleri, 


\title{
Opinions of English Teachers on Computer Based DynEd English Curriculum
}

\begin{abstract}
With the influence of technology, it is not enough for people to know a foreign language in a globalized world. As a result of this, people need to learn more than one foreign language. English has become a common language of technology and has become a universal language, a language that everyone should know. The Ministry of National Education is implementing the DynEd program in schools to support English language education in secondary and high schools. The aim of this study is to reveal the benefits of DynEd English language education software that has been implemented since 2008 or the problems in practice. For this purpose, a qualitative study was conducted with 12 English teachers working in 6 secondary and 6 high schools. Data were collected through a semi-structured interview form. Content analysis method was used for data analysis. The teachers stated that there are deficiencies in technological infrastructure in DynEd applications and that there are problems in smartphone applications that cannot be installed on some phones due to operating system problems. The teachers stated that DynEd cannot be the sole solution for the problems in English language education, but can only support language education.
\end{abstract}

Keywords: English language training, computer-based training, students and teachers technological competences 


\section{Giriş}

Teknoloji ve internetin çok hızlı geliştiği günümüzde eğitim bilimciler, bilgisayar yazılım şirketleri Bilgi İletişim Teknolojilerinden (BİT) yabancı dil eğitiminde etkili kullanılmasına yönelik çalışmalar yürütmektedir. Teknoloji çağında internetin sağladığı imkânlar ile ülkeler arasında sınırlar kalkmakta, buralarda yaşayanlar için iletişim bir zorunluluk haline dönüşmektedir. $\mathrm{Bu}$ ülkeler arasındaki iletişimde teknoloji dili olması ve yaygın kullanımı nedeniyle İngilizce tercih edilmektedir. Dünyada pek çok ülke öğrencilerine İngilizce öğretebilmek amacıyla ilkokuldan itibaren İngilizceyi müfredatlarına dahil etmişlerdir. Ancak İngilizcenin öğretilmesi müfredata dahil olma ile aynı hızda gerçekleşmemiş, öğretimde birtakım zorluklar yaşanmıştır (Enever and Moon, 2009). Yaşanan zorlukların bir kısmı bütün ülkeler için ortak iken, bazıları da yerel ve bölgesel farklılıklardan kaynaklanmıştır. Örneğin Japonya'da İngilizce eğitimi okullar ve yerel yönetimlere bırakılırken, Kore'de merkezi hükümet tarafından gerçekleştirilmektedir. Bu eğitim politikaları ve dil eğitimine erişim imkânlarındaki farklılıklar eğitim düzeylerinde de farklılaşmasına neden olmaktadır (Butler, 2009).

Türkiye'de Millî Eğitim Bakanlığı (MEB) öğrencileri geleceğe hazırlamak, 21.yüzyıl becerileri ile donatmak ve dijital çağa hazırlamak amacıyla 2017 y1lında İngilizce dersini ilkokul 2. sınıftan başlamak kaydıyla ilk ve ortaöğretimin bütün kademelerinde zorunlu ders kapsamına almıştır (Talim Terbiye Kurulu Başkanlığı, 2017). Müfredatta yapılan bu değişiklikle birlikte MEB 2023 vizyon belgesinde yabancı dil öğretmenlerinin genel ve özel alan yeteneklerinin geliştirilmesi amacıyla uluslararası programlara katılmalarına firsat yaratılacağı belirtilmiştir (MEB, 2017a).

MEB tarafından yıllardır yabancı dil eğitiminin iyileştirilmesine yönelik girişimler ve eğitim politikaları uygulanmasına rağmen, yabancı dil öğreniminde önemli sorunlar ile karşılaşılmaktadır (İşler ve Günbayı, 2017). Bu sorunlardan bir tanesi öğretmenlerin gramer odaklı eğitim uygulamasından kaynaklanmaktadır. Gramer odaklı eğitimde, öğrencilerin sözel olarak kendilerini ifade edememekte ve yabancı dil öğrenmeye karşı olumsuz tutum sergilemelerine neden olmaktadır. (Kırkıç, 2019). Türk Eğitim Derneği tarafından 1983 yılında düzenlenen Orta Öğretim Kurumlarında Yabancı Dil Öğretimi ve Sorunları başlıklı çalıştayda o dönemlerde de dil öğretimi ile ilgili 
benzer sorunlar olarak kalabalık sınıfların olması, derslerde Türkçe konuşulması, öğrencilerin motivasyon eksiklikleri gösterilmekte, bunların çözümü için ise İngilizce derslerinin filmler, slaytlar ve kasetlerle desteklenmesi gerektiğine vurgu yapılmaktadır (TED, 1983). Dil eğitiminde yaşanan problemler eğitimcileri yeni arayışlara iterek bilişsel düzeyden sosyo-bilişsel düzeye itmiş, farklı dil becerilerini (dinleme, okuma, yazma, konuşma) teknoloji destekli entegrasyona yöneltmiştir (Tafazoli ve Golshan, 2014).

Ülkemizde yabancı dil eğitiminde başarıya ulaşılması için farklı yöntemlerin uygulanması ve İngilizce eğitimlerin bilişim teknolojileri ile desteklenmesine ihtiyaç duyulmaktadır (Kozikoğlu, 2013). Yabancı dil eğitiminde dil laboratuvarlarında teknoloji destekli eğitimler verilmektedir (Lee, 2000; Meena, 1997). Yabancı dil sinıflarına yeni teknolojilerin entegrasyonu, dil eğitiminde yaşanan problemlerin çözümüne katkı sağlayabilir (Tafazoli ve Golshan, 2014). Bilgisayarlar şekil, ses, grafik vb. görsel ve işitsel öğelerle destekli yazılımlarla öğrencilerin motivasyonlarını artırarak bireysel öğrenmelerine katkı sağlayabilir (Kaplan, Öztürk, Altaylı ve Ertör, 2013). Öğrenciler okul haricinde bilgisayarlar ile saatlerce vakit geçirebilmekte, bunda da bilgisayarların sağlamış olduğu içsel motivasyon etkili olmaktadır (Baek, 2008). Bilgisayarlar uygulamalarda öğrenciye fırsat eşitliği, etkileşim ve tek bir kaynağa bağımlı kalmadan evrensel bir bakış getirmesi gibi sebeplerle (Lee, 2000) eğitimde daha çok tercih edilir hale getirmektedir.

DynEd (Dynamic and Education-Dinamik ve Eğitim) yazılımı MEB tarafından ilk olarak 2008-2009 Eğitim-Öğretim yılında ilköğretim kurumları 4, 5, 6, 7 ve 8. sinfflarında uygulamaya konulmuştur. Ortaöğretim kurumları 9, 10, 11 ve 12. Sınıflarında ise 2014-2015 Eğitim-Öğretim yılında uygulanmıştır. DynEd Amerikan menşeili olup, DynEd International Inc. firmasının desteği, Oxford University Press, Longman, Prentice Hall, BBC ve Stanford University gibi eğitim kurumları ile Apple, IBM, SONY, and NEC gibi teknoloji firmalarının katkısı ile uzman eğitimciler, bilgisayar programcıları ile oluşturulmuş 13 milyondan fazla aktif kullanıcısı olan bir yazılımdır (https://gaziantep.meb.gov.tr, 2019). DynEd dil eğitimcileri, bilgisayar yazılımclları, nörologlar ve sanatçların ekip çalışması ile oluşturulmuş çoklu ortam yabancı dil eğitimi programı olarak bilinmektedir. DynEd nöro-bilimsel yöntemlerle bilginin hafızada kalmasını destekleyen dil eğitimini bilgisayar ortamına taşıyan ve gerçek hayat benzeri uygulamalarla bireylerin kendi kendilerine İngi- 
lizce öğrenmelerini sağlayan bir eğitim yazılımıdır. DynEd yazılımı ile öğrenciler dinleme, konuşma ve yazma etkinlikleri yapabilmektedir. Öğrenciler programı hem okulda hem de evlerinde kullanabilmekte, öğretmenler öğrencileri bütün aşamalarında izleyebilmektedir. Yazılımın, öğrencinin kendi dil seviyesine uygun düzeyde çalışabilmesi için başlangıçta seviye sınavı yapmaktadır (MEB, 2017b).

Yabancı dil eğitiminde yaşanan bu problemlerin çözümüne yönelik eğitim politikalarında değişiklikler yapılmasına rağmen hala problemler yaşanmaktadır (İşler ve Günbayı, 2017). MEB dil eğitiminde yaşanan problemlerin çözümüne destek olması amacıyla DynEd İngilizce öğretim yazılımı ve BDE uygulamasını ortaöğretim kurumlarında zorunlu hale getirmiştir. Ancak uygulamada birtakım problemlerle karşılaşılmaktadır. Bu problemler arasında öğretmenlerin teknoloji tabanlı uygulamalara direnci, teknik ve teorik problemler, yazılım ve donanım, bakım onarım, personel eksikliği ile ekonomik maliyetler sayılabilir (Lee, 2000). Eğitim alanında uygulamaya konulan değişikliklerde öncelikle öğretmenlerin bu değişime inanması, teknoloji ve bilim alanındaki yeniliklerin farkında olması gereklidir (Baki, 2001; Kozikoğlu, 2013). Eğer öğretmenlerin yazılım ve donanımla ilgili teknolojik bilgisi yetersiz ise sınuflarında dijital materyal geliştirme ve kullanmada zorlanabilirler Baki, 2001). Bilgisayarlar ve yazılımlar ne kadar basit olursa olsun, öğrencilerin bunları kullanmak için belli bir beceriye sahip olmaları gerekir (Gündüz, 2005). BDE' in başarılı bir şekilde uygulanabilmesinde öğrenci ve öğretmenlerin bilgisayar yazılımlarını kullanma becerileri önemli bir faktördür (Şengel, Öncü ve Göktalay, 2014). BDE kullanılan yazılımlar öğrenciler için geliştirilmesine rağmen, bu yazılımları öğrencilere öğretme ve eksikliklerini tespit etme becerisine sahip öğretmenlere ihtiyaç vardır. Öğretmen desteği olmadan bilgisayarlar ve yazılımları tek başına değildir (Gündüz, 2005).

DynEd ile ilgili ülkemizde yapılan yüksek lisans ve doktora tezleri incelendiğinde 2010 yılından itibaren dokuz yüksek lisans, bir doktora tez çalışmasının yapıldığı görülmüştür. Bu çalışmalarda, Uras (2018), DynEd'in öğrenci başarısını olumlu etkilediği, öğrencilerin İngilizce dersine karşı olumsuz görüşlere sahip olmalarına rağmen, DynEd yazılımına karşı olumlu görüş içerisinde olduklarını belirtmektedir. DynEd eğitim yazılımı, öğrencilerin gramer bilgisi, kelime bilgisi, okuma, dinleme ve akademik başarı ile bireysel öğrenmelerini olumlu etkilerken (Çakmak, 2012; Meri, 2011; Önal, 2015; Selçuk, 2016), konuşma ve yazma becerilerinde o kadar etkili olmamaktadır 
(Çakmak, 2012). Öğrenciler yazılımın gerekliliği konusunda olumlu görüşe sahip olmalarına rağmen (Ucur, 2010), özyönetim, farkındalık, eleştirel, yansıma, kendini değerlendirme gibi özerklik becerilerini kazandırmada önemli bir fark yaratmamaktadır (Mete, 2010). Coşkun (2013) İngilizce öğretmenlerinin büyük bir çoğunluğunun DynEd uygulaması sınıflarında kullanmadıklarını, kısmen olumlu görüş geliştirdikleri belirtmektedir. Öğretmenlerin olumsuz görüş bildirmesinde bilgisayar bilgilerinin yetersiz olduğuna dair genel bir kanaat olmasına rağmen, yapılan çalışmada bilgisayar bilgisinin öğretmenlerin DynEd'e karşı tutumları üzerinde hiçbir etkisi olmadığını göstermiştir (Yiğit, 2010). Öğretmenlerin DynEd'i kullanmaktan kaçınmasına neden olan donanım eksikliği (bilgisayar, mikrofon, kulaklık, vb.), İnternet bağlantısı sorunu, yoğun müfredat, kalabalık sınıflar, yetersiz sunucular, teknik problemler ve yöneticilerin olumsuz tutumları yer almaktadır (Coşkun, 2013; Meri, 2011; Sarıcaoğlu, 2010; Yiğit, 2010).

MEB tarafından 2008 yılından beri uygulanmaya çalışılan DynEd İngilizce dil eğitim yazılımının sınıflarda kullanımında birtakım problemler yaşanmaktadır. Bu problemlerin tespitinde DynEd İngilizce eğitim yazılımını okullarda yürütmekte olan İngilizce öğretmenlerinin görüşleri önemli görülmektedir. Bu amaç doğrultusunda ortaokul ve liselerde görev yapan İngilizce öğretmenleri ile yapılacak nitel bir çalışma konu hakkında derinlemesine bilgi sahibi olunmasını sağlayabilir. DynEd İngilizce dil eğitim yazılımının öğrencilerin İngilizce öğrenmelerine katkıları ya da yaşanan sorunlar hakkında öğretmen görüşleri alanyazına katkı sağlayabilir. Bu amaç doğrultusunda kamuya bağlı ortaokul ve liselerde görev yapan İngilizce öğretmenlerinden aşağıdaki sorulara cevaplar vermeleri istenmiştir.

- Okullarda uygulanan İngilizce dil eğitimini başarılı buluyor musunuz? Neden?

- Bilgisayar destekli DynEd İngilizce dil eğitim programı hakkında ne düşünüyorsunuz?

- İngilizce dil eğitimine katkısı nedir?

- Uygulamada yaşanan problemler nelerdir?

- DynEd sınıf içerisinde daha aktif nasıl kullanılabilir? 


\section{Yöntem}

\section{Araştırmanin deseni}

Araştırmada, ortaokul ve liselerde görev yapan İngilizce öğretmenlerinin DynEd İngilizce dil eğitim yazılımının yabancı dil eğitimine katkısı konusunda görüşleri alınmıştır. Araştırmada nitel yöntemlerden olgu bilim kullanılmıştır.

Olgu bilim, farkına vardığımız ancak konu hakkında derinlemesine fikir sahibi olmadığımız olgularla ilgilidir. Olgulara yaşadığımız dünyada deneyimler, algilar, yönelimler ve durumlar olarak çevremizde rastlayabiliriz. Veri kaynakları ise olguyu yansitabilecek, yaşayan ya da dişa vurabilecek kişi ya da gruplardan oluşmakta olup, veriler görüşme yoluyla elde edilir (Yıld1rım ve Şimşek, 2011). Yapılan araştırmadaki olgu ya da olay, ortaokul ve liselerde görev yapan İngilizce öğretmenlerinin DynEd dil eğitim yazılımı hakkındaki görüşleridir.

\section{Katılımcilar}

Araştırmada olgu ve olayların keşfedilmesi ya da açıklanması için amaçlı örneklem yöntemlerinden maksimum çeşitlilik örneklemesi kullanılmıştır. Bu yöntemin kullanılmasının amacı, göreli olarak küçük bir örneklem oluşturmak ve bu örneklemde çalışılan probleme taraf olabilecek bireylerin çeşitliliğini maksimum derecede yansıtmaktır (Yıldırım ve Şimşek, 2011). Araştırma ortaokullarda 6 (ortaokul, imam hatip ortaokulu), liselerde (Anadolu lisesi, fen lisesi, meslek lisesi) 6 olmak üzere toplam 12 İngilizce öğretmeni ile yürütülmüştür. Farklı türde okulların seçimi ile maksimum çeşitlilik sağlanmaya çalışılmıştır. Araştırmaya katılan öğretmenlerin demografik özellikleri Tablo 1 'de verilmiştir.

Tablo 1 incelendiğinde görüşme yapılan öğretmenlerin 2'si erkek, 10'u kadındır. Mesleki kıdemlerine bakıldığında kıdemi 6-10 yıl arasında olan öğretmen 1 iken, geriye kalan öğretmenlerin 11'i 11 yıl ve üzeri mesleki kıdeme sahiptir. Bu öğretmenlerden 1'i doktora, 11'i lisans mezunudur. Bu öğretmenlerden 6'sı ortaokulda görevde yapmakta olup 6'sı ise lisede görev yapmaktadır. 
Tablo 1. Katılımcilarn demografik bilgileri

\begin{tabular}{lll}
\hline & & $\mathbf{N}$ \\
\hline Cinsiyet & Erkek & 2 \\
& Kadın & 10 \\
\hline Kıdem & $6-10$ yıl & 1 \\
& $11-15$ yıl & 2 \\
& $16-20$ yll & 6 \\
& 21 ve üzeri & 3 \\
\hline Eğitim Düzeyi & Lisans & 11 \\
& Doktora & 1 \\
\hline Okul Türü & Ortaokul & 5 \\
& Imam Hatip Ortaokulu & 1 \\
& Mesleki ve Teknik Anadolu Lisesi & 3 \\
& Anadolu Lisesi & 2 \\
& Fen Lisesi & 1 \\
\hline
\end{tabular}

\section{Veri toplama araçlar}

Bu çalışmada, İngilizce öğretmenlerinin DynEd İngilizce dil öğretim yazılımının okullarda uygulanmasına ilişkin görüşlerinin detaylı bir şekilde ortaya konulması amacıyla yapılandırılmış görüşme formuyla veriler toplanmıştır.

Araştırmada görüşme formu kullanılarak katılımcılara önceden hazırlanan sorular yöneltilmiştir. Görüşme esnasında araştırmacı bu sorulara ek sorular sorarak konu hakkında ayrıntılı bilgiye sahip olabilir, verileri hızlı analiz edebilir ve araştırmanın kapsamı ile karşılaştırma yapabilir (Büyüköztürk, Çakmak, Akgün, Karadeniz ve Demirel, 2012; Türnüklü, 2000; Yıldırım ve Şimşek, 2011). Görüşme formu oluşturulurken DynEd ile ilgili yapılmış akademik çalışmalar ile BDE ve BITT'in eğitim ortamlarında kullanılmasına yönelik araştırmalar göz önünde bulundurulmuştur.

Görüşme formu oluşturulurken, İngilizce öğretmenliği alanında lisans derecesine sahip ve Türkiye' de bir devlet üniversitesinde eğitim bilimleri bölümünde öğretim üyesi olarak görev yapan bir uzmanın görüşüne başvurulmuştur. Görüşüne başvurulan öğretim üyesi, MEB'de öğretmenlik yapmış ve görev yaptığı süreler içerisinde DynEd ilçe koordinatörlüğü görevini yürütmüştür. Öğretmen görüşlerinin ayrıntılı bir biçimde elde edilebilmesi amacıyla, kapalı uçlu sorular yerine açık uçlu sorular tercih edilmiştir. Öğretmenlerin sorulara evet/hayır şeklinde kısa cevap vermeleri durumu göz önünde bulundurularak alternatif sorular hazırlanarak konu hakkında derinlemesine 
bilgi edinilmeye çalışılmıştır. Hazırlanan görüşme soruları ile araştırma öncesinde bir İngilizce öğretmeni ile pilot uygulama gerçekleştirilmiştir. Pilot uygulama esnasında kayıt altına alınan görüşmeler eğitim bilimleri bölümünde görev yapmakta olan iki akademisyen tarafından analiz edildikten sonra analizler karşılaştırılarak uygunluğuna karar verilmiştir.

Görüşme soruları ve sonda sorular aşağıdaki gibi belirlenmiştir.

- Ülkemizdeki yabancı dil eğitimi hakkında ne düşünüyorsunuz? Sizce yabancı dil eğitiminde başarılı mıyız? Neden?

- DynEd dil eğitim programı hakkındaki görüşleriniz nelerdir?

- DynEd uygulama sırasında yaşadığınız sorunlar nelerdir? Sorunlarınızı nasıl çözüyorsunuz?

- DynEd'in İngilizce öğretimine katkısı konusunda ne düşünüyorsunuz?

- DynEd mobil uygulaması hakkında ne düşünüyorsunuz?

- DynEd uygulamasının aktif kullanılması ve başarılı olunması için çözüm önerileriniz nedir?

\section{Verilerin Toplanma Süreci}

Araştırma verileri yarı-yapılandırılmış görüşmeyle toplanmıştır. Araştırmanın verileri 15-30 Haziran 2019 tarihleri arasında görüşmecilerin görev yaptıkları okullara gidilerek gerçekleştirilmiştir. Görüşmeler en kısa 11 dakika, en uzun ise 35 dakika sürmüştür. Ortalama görüşme süresi 18 dakika olarak gerçekleşmiştir. Görüşme öncesi araştırmanın amacı hakkında öğretmenlere bilgi verilerek, görüşmenin kayıt altına alınabilmesi için onay alınmıştır. Araştırma soruları ayrı ayrı sorularak kendilerine cevap vermeleri için yeterli zaman tanınmıştır.

\section{Verilerin Dökümü Ve Analizi}

Öğretmenlerin verdikleri yanıtlar, içerik analiz tekniği ile analiz edilip, temalar ve kodlar oluşturulmuştur. Veriler sayısallaştırılıp, araştırma bulguları yorumlanmıştır. İçerik analizinde veriler betimsel olarak fark edilmeyen kavram ve temaların keşfedilmesi sağlanır. Birbirine benzeyen veriler belirli kavram ve temalar çerçevesinde bir araya getirilir, okuyucunun anlayabileceği bir biçimde düzenlenerek yorumlanır (Yıldırım ve Şimşek, 2011). 
Veriler iki uzman tarafından ayrı ayrı kodlanmıştır. Kodlar tema ve alt kategorilere ayrılmıştır. Uzmanlar tarafından belirlenen kodlar incelenerek görüş birliği ve görüş ayrıllğı olan kodlar belirlenmiştir. Belirlenen bu kodlardan hareketle görüşler arasındaki uyum oranı belirlenmiştir. Bu oranın hesabında Miles ve Huberman'ın (1994) güvenirlik formülü kullanılmıştır [Güvenirlik Formülü: Görüş Birliği/ (Görüş Birliği+ Görüş Ayrılı̆̆ı) x100]. Nitel çalışmalarda, uzman ve araştırmacı değerlendirmelerinin sonucunda aralarındaki uyumun \%90 ve üzeri olması güvenirlik oranını sağlamış olur (Saban, 2008). Yapılan hesaplamada görüş birliğinin \%90'ın üzerinde olduğu görülmüştür. Bu orana göre çalışmanın güvenilir olduğu söylenebilir.

Uzman tarafından temalar kontrol edilerek geçerliliği sağlanmıştır. Tematik çerçeveye göre verilerin işlenmesi aşamasında, belirlenen çerçeveye göre veriler düzenlenmiştir. Verilerin tanımlanması için, veriler anlamlı ve mantıklı bir biçimde bir araya getirilmiştir. Bu arada önemsiz görülen veriler d1şarıda bırakılmıştır. Düzenlenen veriler tanımlanırken, anlaşılır ve okunabilir olmasına dikkat edilmiştir. Bulgular yorumlanırken ise, bulgular ilişkilendirilmiş, neden-sonuç iliş̧isi içerisinde açılanmış ve karşılaştırmalar yapılmıştır (Yıldırım ve Şimşek, 2011).

\section{Geçerlilik ve Güvenirlilik Sağlama Aşaması}

Araştırma sonuçlarının geçerlilik ve güvenirliliği sağlaması adına araştırma yoluyla gerçeğin doğru temsili, sonuçların uygulanması, tutarlılı̆̆ı sağlama, nesnel ve yansız olma ölçütlerini kullanılmış olup (Yıldırım ve Şimşek, 2011) bunlar Tablo 2' de verilmiştir.

Tablo 2. Geçerlilik ve güvenirlik ile ilgili uygulamalar

\begin{tabular}{lll}
\hline Ölçüt & & Kullanılan Yöntemler \\
\hline Geçerlilik & İnandıııcllk & Uzman incelemesi \\
& & Katılımcı teyidi \\
\cline { 2 - 3 } & Aktarılabilirlik & Ayrıntılı betimleme \\
& & Amaçlı örnekleme \\
\hline Güvenirlilik & Tutarlık & Tutarlık incelemesi \\
\cline { 2 - 3 } & Teyit edilebilirlik & Teyit incelemesi \\
\hline
\end{tabular}

Araştırmada inandırıcılı̆̆ın sağlanabilmesi adına araştırmada elde edilen bütün veriler ve çalışmanın son hali bir uzman akademisyene gönderilerek 
uzman incelemesi gerçekleştirilmiştir. Başkale'e (2016) göre, sonuçların inandırıcılığı, bilimsel araştırmanın en önemli ölçütlerinden biri olarak kabul edilmektedir. Katılımcı teyidinin alınması için araştırma bulguları katılımcılara e-posta ile gönderilerek bulguların ifade etmeye çalıştıkları konularla örtüşüp örtüşmediğine dair görüşleri alınmıştır. Sonuçların aktarılabilir liginin (transfer edilebilirlik) sağlanması adına bulgular kısmında katılımcıların görüşlerini aynen yansıtan doğrudan ifadelere yer verilmiştir. Örneklem seçiminde ise amaçlı örneklem yöntemi kullanılmış olup, teknolojik alt yapısı iyi olan ve alt yapıyı orta düzeyde olan okulların İngilizce öğretmenleri ile görüşmeler gerçekleştirilmiştir. Ortaokullarda çalışmaya imam hatip ortaokulu dâhil edilmiştir. Liselerde ise farklı okul türleri (Anadolu, fen, meslek) ve öğrenci başarısı farklı düzeyde olan okullarda araştırma gerçekleştirilmiştir. Geçerlilik için gerekli olan tutarlılığın sağlanması için görüşmeler kayıt altına alınmış olup, teyit incelemesi için dijital ortamda muhafaza edilmektedir. Nitel araştırmalarda ses kayıtlarının alınması, katılımcının görüşlerine ekleme yapılmadan olduğu gibi yazıya aktırılması güvenirliği artırmaktadır. Verilerin eksiksiz ve yanlışsız kayıt edilmesinde birden fazla araştırmacının, veri kaynağını kullanması sonuçların güvenirliliğini artıracaktır (Büyüköztürk vd., 2012).

\section{Bulgular}

Yapılan araştırmada katılımclardan elde edilen bilgiler iki başlık altında toplanmıştır. Birinci olarak ülkemizde dil eğitiminde yaşanan sorunlar ve çözüm önerileri yer almıştır. İkinci olarak ise DynEd İngilizce eğitimi hakkında katılımcıların görüşleri yer almıştır.

\section{İngilizce Dil Eğitiminde Yaşanan Sorunlar Ve Çözüm Önerileri}

Araştırma katılımcılarından elde edilen verilerin analizi neticesinde İngilizce dil eğitiminde yaşanan sorunlar başlığı altında Eğitim Sistemi, Donanım, Ders İçerikleri, Öğretmen ve Öğrenci Kaynaklı sorunlar olmak üzere beş tema ve bu temalara ait kodlar belirlenmiş olup Tablo 3'de verilmiştir. 
Tablo 3. Ingilizce dil eğitiminde yaşanan sorunlar

\begin{tabular}{|c|c|c|c|}
\hline Kategori & Kodlar & & $\mathrm{f}$ \\
\hline \multirow{5}{*}{$\begin{array}{l}\text { Eğitim } \\
\text { Sistemi }\end{array}$} & Ders saatlerinin az olması & Ö1,Ö3, Ö5,Ö6,Ö10,Ö12 & 6 \\
\hline & Sinıf mevcutlarının fazla olması & Ö4,Ö10 & 2 \\
\hline & Hazırlık sınıfının olmaması & Ö3,Ö12 & 2 \\
\hline & Eğitim sistemi değişikliği & Ö7 & 1 \\
\hline & Üst düzey İnilizce öğretme çabası & Ö7 & 1 \\
\hline \multirow[t]{2}{*}{ Donanım } & $\begin{array}{l}\text { Bilgisayar, dil laboratuvarı, } \\
\text { projeksiyon, Akıllı tahta, kulaklık }\end{array}$ & Ö1,Ö5,Ö6,Ö8,Ö10 & 5 \\
\hline & Materyal eksikliği & Ö4 & 1 \\
\hline \multirow{7}{*}{$\begin{array}{l}\text { Ders } \\
\text { İçerikleri }\end{array}$} & Günlük hayatta kullanılmaması & Ö1,Ö2,Ö5,Ö10,Ö11,Ö12 & 6 \\
\hline & Dinleme uygulaması yetersiz & Ö5,Ö6,Ö12 & 3 \\
\hline & Konuşma uygulaması yetersiz & Ö5,Ö6,Ö9 & 3 \\
\hline & Telaffuz eğitiminin verilememesi & Ö5,Ö11 & 2 \\
\hline & Gramer ağırlıklı olması & Ö11 & 1 \\
\hline & Yazma uygulaması yetersiz & Ö5 & 1 \\
\hline & Meslek liselerine uygun olmaması & Ö4 & 1 \\
\hline \multirow{3}{*}{$\begin{array}{l}\text { Öğretmen } \\
\text { Kaynaklı }\end{array}$} & Öğretmenin almış olduğu eğitim & Ö10 & 1 \\
\hline & Öğretmenin hizmetiçi eğitim ihtiyacl & Ö10 & 1 \\
\hline & Teknolojiye karşı gösterdiği direnç & Ö10 & 1 \\
\hline \multirow{2}{*}{$\begin{array}{l}\text { Öğrenci } \\
\text { Kaynaklı }\end{array}$} & Hazır bulunuşluluk düzeyi & Ö4,Ö8 & 2 \\
\hline & Öğrenci başarı düzeyi & Ö4 & 1 \\
\hline
\end{tabular}

Tablo 3 incelendiğinde İngilizce dil eğitiminde yaşanan sorunların olarak öğretmenler Ĕ̆itim Sistemi kaynaklı olarak ilk sırada ders saatlerinin yetersiz olduğunu, sırasıyla sınıf mevcutlarının fazlalığı, hazırlık sınıflarının bulunmaması, sistem değişiklikleri ve üst seviyede İngilizce öğretme çabası olarak görüş belirtmişlerdir. Ders saatinin fazla olması ile ilgili Ö5, “. ..3 saat çocuğa speaking mi ögreteceksin, writtening mi, listening mi hangisini yaptıracaksin? Bir de üstüne DnyEd isteniyor. Bu çocuğa 2 saat mi sadece sen müfredatı işleyeceksin? Sonrasında 1 saati de DynEd'e mi ayıracaksın?" şeklinde görüş bildirmiştir. Sınıf mevcutları ve zamanın yetersizliği ile ilgili olarak Ö10, “...sımıfta bunu çözmeye kalktığınız yaklaşık 36-37 öğrencimiz var, mümkün değil yani. Diğer kazanımları gerçekleştirmeye çalışırken DynEd'i aynı anda götüremiyorsunuz. Sinıf içi ders saatimiz bu noktada yeterli değil." demektedir.

Dil eğitiminde yaşanan sorunlar olarak öğretmenler teknolojik donanım (Bilgisayar, dil laboratuvarı, projeksiyon, akıllı tahta, kulaklık vb.) eksikliklerini görmektedir. Donanım eksiklikleri ile Ö1, “... bilgisayar laboratuvarmda hoporlör, kulaklık yok, teknik destekte olmayınca bilgisayar laboratuvarmı kullanamıyoruz" derken, Ö8 ise “...bizim okulumuzda akull tahtalarımı var, ancak internet alt 
yapısı yok", Ö6 “...dil laboratuvarımız yok, tek bir bilgisayarmız var oda öğretmen masasında" şeklinde görüşlerini dile getirmişlerdir.

Dil eğitiminde yaşanan sorunları ders içerikleri bakımından değerlendiren öğretmenlerin 8'i dilin günlük hayatta kullanılmaması, dinleme, konuşma, yazma ve telaffuz uygulamalarının yetersiz, bir öğretmen bunlarla birlikte gramer ağırlıklı bir eğitim olduğunu belirtirken, bir öğretmen ise eğitim müfredatının meslek liselerine uygun olmadığı görüşünü dile getirmiştir. Ö1, “...biz dili yaşayıp kullanamıyoruz. Kullanamadığımız için de başarıl olamıyoruz." Ö2, "...böyle hayatın içinde ya da yabancı biriyle karşılaşınca onla iletişim kuramyor. What is your name, How are you'dan öteye geçemiyorlar." Ö5, "...daha fazla pratiğe yönelik şeyler yapılması gerektiğine düşünüyorum ben, sadece gramer anlatımından ziyade speaking, listening, writtening bu alanlarda da çocuğu geliştirmek gerektiğini düşünüyorum." Ö9, "...şöyle bir gerçek var, öğretiyoruz ama konuşturamıyoruz." Ö11, “...Ingilizce öğretmenin Türk olmaması gerektiğini düşünüyorum.” Ö12, “...ders gibi değil, hayatının içine girmesi lazım çocuğun. Onu yaşaması, duyması, hissetmesi lazım."

Dil eğitiminde yaşanan sorunlar ile ilgili görüş bildiren bir öğretmen, öğretmenlerin lisans döneminde aldıkları eğitimin yetersiz olduğunu, teknoloji destekli eğitime karşı direnç gösterdiklerini ve bu konuda hizmetiçi eğitime ihtiyaçları olduğu, Ö10" ...öğretmen arkadaşlarm aldığı eğitimden kaynaklanıyor belki. Çok daha interaktif eğitim almadık." şeklinde görüş bildirmiştir.

Dil eğitiminde yaşanan sorunlar arasında öğrencilerin hazır bulunuşluluk düzeyleri konusunda fen lisesinde çalışan bir öğretmen yeterli görmekte iken, ortaokulda çalışan bir öğretmen ise hazırbulunuşluluk düzeylerinin yetersiz olduğunu, Ö4 “...çocuklar hazır bulunuşluk seviyesinde değiller." şeklinde görüş bildirmiştir.

Araştırma katılımclarından elde edilen verilerin analizi neticesinde İngilizce dil eğitiminde yaşanan sorunlara çözüm önerileri başlığı altında Müfredat, Süre, Yöntem, Öğretmen ve Materyal olmak üzere beş tema ve bu temalara ait kodlar belirlenmiş olup Tablo 4'te verilmiştir. 
Tablo 4. Ingilizce dil eğitimine çözüm önerileri

\begin{tabular}{llll}
\hline Kategori & Kodlar & & f \\
\hline \multirow{2}{*}{ Müfredat } & Oyun tabanlı & Ö1,Ö4,Ö7,Ö12 & 4 \\
\cline { 2 - 4 } & Konuşma ağırlıklı olmalı & Ö8,Ö12 & 2 \\
\cline { 2 - 4 } & Okula göre müfredat & Ö3 & 1 \\
\hline Süre & Ders saatlerinin artırılması & Ö11 & 1 \\
\hline \multirow{2}{*}{ Yöntem } & Yabancı dil kampı & Ö2,Ö11 & 2 \\
\cline { 2 - 4 } & Teknoloji desteği & Ö10 & 1 \\
\cline { 2 - 4 } & Yabancı biriyle konuşma & Ö1 & 1 \\
\hline Öğretmen & Anadili İngilizce olan öğretmen & Ö11 & 1 \\
\hline Materyal & Çizgi film destekli ve farklı materyal & Ö2,Ö7,Ö12 & 3 \\
\hline
\end{tabular}

Tablo 4 incelendiğinde İngilizce dil eğitiminde yaşanan sorunlara çözüm olarak öğretmenler müfredat kategorisi altında oyun tabanlı eğitimi görmektedir. Ö1, “... oyun oynamayı DyneEd yapmaya tercih ettiklerini gözlemledim.” Ö5, "...Ingilizceyi oyun düzeyinde anlatılması gerekir. Mesela programda hayvanlar ünitesi oluyor, bu havyalar ünitesinde geçen kelimeleri bir zihin haritası şeklinde çocuklarm oynayabilecekleri şekilde bir oyunla öğretebilir." Ö7, "Bugünün çocuklarn eğlenceli şeyler arıyor, heyecan verici, eğlenceli, oyun içerisinde. Hep ne diyoruz biz. Oyunlarla öğretelim, çocuklarn merkeze alalım.” Ö9, “...milli eğitimin ürettiği bir sistem olsun, milli bir sistem olur milli oyunlar olur." şeklinde görüşlerini belirtmiştir. Aynı kategori altında iki öğretmen derslerin konuşma ağırlıklı işlenmesi gerektiğini belirtmiştir. Ö8 “...çocukları bol bol konuşturmak lazım, aslında var olan kelime bilgisini, gramer bilgisini ortaya koyacak çalışmalar yapılabilir." Ö3 ise, "...bence meslek liselerinde müfredatı bizim belirlememiz gerekiyor. Bize Fen lisesiyle, Anadolu Lisesiyle, diğer liselerle aynı müfredatı işlememizi istiyorlar."

İngilizce ders saati süre konusunda 6 öğretmen yetersiz olduğunu belirtirken, iki öğretmen ders sürelerinin artırılması gerektiğini, bunlardan Ö5, “...ders saati olarak yetmiyor. Ders saatlerinin artırmaları lazım." şeklinde çözüm önerisi getirmiştir.

İngilizce dil eğitiminde yöntem konusunda çözüm önerisi getiren iki öğretmen yabancı dil kamplarının gerekliliğini, bir öğretmen yabancı biriyle konuşma, bir öğretmen ise, teknoloji destekli eğitimin gerekliliğini belirtmişlerdir. Ö11, “...sorunların çözülebilmesi için dil kampları olması lazım.” Ö10, “...öğretmenlerin teknoloji destekli eğitim alması gerekiyor."

Öğretmen boyutunda İngilizce dil eğitimine çözüm olarak bir öğretmen anadili İngilizce olan öğretmenler tarafından İngilizce eğitiminin verilmesi gerektiğini belirtmiştir. Ö11, “...ben kendim İngilizce öğretmeni olduğum halde 
bir İngilizce öğretmenin Türk olmaması gerektiğini düşünüyorum bana kalırsa bir dili, o dilin kendi ana dili olan kişisinden öğrenmek gerekiyor."

Dil eğitimine çözüm olarak materyal konusunda iki öğretmen çizgi film destekli ve farklı materyallerin kullanılması gerektiği görüşünü bildirmişlerdir.Ö12, “...ben öğrencilerime yabancı şarkılar dinlemek, yabancı filmler, çizgi filmler seyretmelerini ben öneriyorum.” derken, Ö2 “...daha çok hayata katan şeyler mesela, çizgi film tarzında küçük şeylerde..." İngilizce eğitimine destek olabileceğini belirtmiştir.

\section{İngilizce Öğretmenlerinin Dyned Dil Ĕ̆itim Programı Hakkındaki Görüşleri}

Bu bölümde araştırmaya katılan İngilizce öğretmenleri ve öğrencilerin teknoloji kullanım yeterlikleri, öğrencilerin DynEd kullanımları ve ilgi düzeyleri, kullanımdaki sorunları, eğitime katkısı ve DynEd etkili kullanılması için öğretmen önerilerinden oluşan temalar yer almaktadır.

Öğretmen ve öğrencilerin teknoloji kullanım yeterlik düzeyleri ve öğrencilerin DynEd'e yönelik ilgileri

Araştırma katılan öğretmen ve öğrencilerin teknoloji kullanım yeterlikleri ile öğrencilerin DynEd kullanımı ve DynEd'e karşı ilgilerine ait temaların yet aldığ1 kodlar Tablo 5'de verilmiştir.

Tablo 5. Öğretmen ve öğrencilerin teknoloji yeterlikleri ile DynEd'e ilgileri

\begin{tabular}{llll}
\hline Kategori & Kodlar & & f \\
\hline \multirow{2}{*}{$\begin{array}{l}\text { Öğretmen } \\
\text { Teknoloji yeterliliği }\end{array}$} & Yeterliyim & Ö1,Ö4,Ö5,Ö6,Ö7,Ö8,Ö9,Ö12 & 8 \\
\cline { 2 - 4 } & Yetersizim & Ö2,Ö3,Ö10 & 3 \\
\cline { 2 - 4 } & Kısmen yeterliyim & Ö11 & 1 \\
\hline Öğrenci teknoloji yeterliliği & Yeterli düzeyde & Ö1,Ö2,Ö3,Ö4,Ö5,Ö6,Ö7,Ö8,Ö9,Ö10,Ö11,Ö12 & 12 \\
\hline Öğrenci DynEd kullanımı & Çok kolay & Ö1,Ö5,Ö7,Ö9,Ö10,Ö12 & 6 \\
\hline $\begin{array}{l}\text { Öğrenci DynEd'e } \\
\text { yönelik ilgi düzeyi }\end{array}$ & Ilgi çekici değil & Ö1,Ö3,Ö4,Ö7,Ö9,Ö10,Ö11 & 3 \\
\cline { 2 - 4 } & $\begin{array}{l}\text { İgi çekici bulanda } \\
\text { var bulmayanda }\end{array}$ & Ö2,Ö5,Ö12 & 1 \\
\cline { 2 - 4 } & İgi çekici & Ö6 & 7 \\
\hline
\end{tabular}

Araştırmaya katılan öğretmenlerden 8'i teknoloji kullanım düzeylerini yeterli görürken, bir tanesi kısmen yeterli görmekte, geriye kalan 3'ü ise yetersiz görmektedir. Yetersizim diyen öğretmenlerden Ö2, “...böyle ben bilgisayar kullanımında falan sayılarla pek aram yoktur, Biraz zor öğreniyorum.", Ö3 “....yani idare ediyorum ama başka bir liseye gitsem yeterli bulmuyorum kendimi. Bilgisayar 
eğitimim var ama geliştirmeye çalışsam da olmuyor bir türlü olmuyor..." derken, Ö10 “...elbette yeterdi değilim ama mümkün olduğunca teknolojiyi kullanmaya çaışıyorum. Kendimi bu noktada güncellemeye çalışıyorum." şeklinde teknoloji yeterliklerini tanımlamışlardır.

Araştırmaya katılan öğretmenlerin tamamı öğrencileri teknoloji kullanım düzeylerini yeterli görmekte, bunlardan 6'sı ise öğrencilerin DynEd'i çok kolay kullandıklarını belirtmektedir. Yine bu öğretmenlerden 7'si öğrencilerin DynEd'i ilgi çekici bulmadığını, 3'ü ilgi çekende var çekmeyende, 1'i ise öğrencilerin DynEd'i ilgi çekici buldukların belirtmiştir. Bu öğretmenlerin görüşlerinden bazıları şu şekildedir.

- Ö8, “...öğrencilerin teknoloji kullanım yeterliklerinin olduğunu düşünüyorum. Yeni nesil bizden daha aktif kullanıyor interneti, bilgisayarı. Donanımlı olduklarını düşünüyorum."

- Ö1, “...çok az bir kısmı ilgi çekici bulup devamlılığını sağlarken diğerlerinin ilgisini çekemiyor. 250 öğrenciden belki de 10 öğrenci çok ciddi bir başarn sarf etmiştir."

- Ö2, “...yani ne buluyor ne bulmuyor, orta düzeyde."

- Ö4, “...ders haricinde o konularda çok yetenekliler ama istiyorlarsa yaparlar ama istemiyorlar. Tabii kesinlikle yeterlilikleri var."

- Ö5, "...ilgi çekici bulan da var, bulamayan da..."

- Ö7, “...kesinlikle bulmuyorlar. En çalışkan öğrenci bile sıkılıyor. ... bunlara uygun bir eğitim sistemi yok."

- Ö7, "...kullanmama, ilgi çekici bulmama nedenlerini tam olarak bilemiyorum ama bir sürü de alternatifi de var aslında DynEd'in ondan dolayı da olabilir."

- Ö12, “...̈̈̆grencilerin her şey için teknolojik yeterliği var."

DynEd İngilizce dil eğitim yazılımının özellikleri

DynEd İngilizce dil eğitim yazılımı teması altında özellikler, öğrenci takibi ve sık kullanılanlar olmak üzere 3 kategori ile bunlara ait kodlar oluşturulmuştur. Kategoriler ve altında yer alan kodlar Tablo 6 'te verilmiştir. 
Tablo 6. DynEd İngilizce dil eğitim yazılımının özellikleri

\begin{tabular}{llll}
\hline Kategori & Kodlar & f \\
\hline Özellikler & Telaffuz & Ö1,Ö5,Ö6,Ö8,Ö10,Ö12 & 6 \\
& Dinleme & Ö1,Ö6,Ö10,Ö12 & 4 \\
& Konuşma & Ö1,Ö5,Ö6,Ö8,Ö12 & 5 \\
& Yazma & Ö1,Ö5,Ö12 & 3 \\
& Ses kaydı & Ö1,Ö10 & 2 \\
& Yeterlilik sınavı & Ö10 & 1 \\
& Oyun özelliği & Ö10 & 1 \\
& Özdenetim & Ö10 & 1 \\
\hline Öğrenci takibi & Başarı düzeyi & Ö1,Ö2,Ö5,Ö6,Ö10,Ö11,Ö12 & 7 \\
& Sistemde kalma & Ö1,Ö2,Ö5,Ö6,Ö10,Ö11,Ö12 & 7 \\
& Ilerleme ve raporlama & Ö1,Ö2,Ö5,Ö6,Ö10,Ö11,Ö12 & 7 \\
& Eksikliklerini görme ve geri dönüt & Ö1,Ö5,Ö10 & 3 \\
\hline Sık kullanılanlar & Kelime çalısması & O5,Ö6,Ö8,Ö10 & 4 \\
& Boşluk doldurma & Ö2,Ö10,Ö11 & 3 \\
& Test çözme & Ö5,O12 & 2 \\
& Gramer uygulamas1 & Ö3,Ö4 & 2 \\
\hline
\end{tabular}

Araştırmaya katılan öğretmenlerin DynEd'in özellikleri olarak 6'sı telaffuz, 5'i konuşma, 4'ü dinleme, 3'ü yazma, 2'si ses kaydı, 1'i yeterlik sınavı, 1'i oyun ve 1'i özdenetim özelliğini belirtmiştir. Bu kodlara göre öğretmen görüşlerinden bazıları aşağıda verilmiştir.

- Ö1, “...çok fazla okuma evet ama yazma konusunda değil sadece dinleme, konuşma özellikle, listening ve speaking konularında çok faydalı olduğunu düşünüyorum. Duyduklarm kaydediyorlar, kaydettiklerinde kendi seslerini normal orijinal sesle kıyaslama şanslar olduğu için telaffuza da oldukça faydal."

- Ö5, “...hem konuşma soruları var hem yazma soruları var. Speaking ile çocuk telaffuzu duyuyor. Nokta nokta kisıma yerleştireceği şeyi telaffuz ederek duyunca kendi telaffuzu da gelişiyor. Yani yeni yeni kelimeler de öğreniyor."

- Ö8, "...bence telaffuz da çok fazla etkisi var. Özellikle dinleme ve konuşma alanındaki bizim eğitim sistemimizdeki o eksikliği tamamladığını düşünüyorum."

- Ö12, “...Ingilizce ne yaparlarsa yapsinlar mutlaka katkısı vardır. ...biz duyacakları en ufak bir kelimeye, en ufak bir şarkıya bile muhtacız. Mutlaka katkı să̆lar."

- Ö10, “...bir yeterlik smavo var öğrencinin seviyesine göre modül açılıyor. Bu güzel bir şey. Var olan seviyeden doğru ilerliyor çocuk, hani çok basit bir şeyden başlamıyor ve kilitli modülleri kendisi ilerledikçe açıyor. Arada keyifli oyunlar var, dinleme parçalan falan var, kendi sesini kaydedip telaffuzu geliştirme şansı var diyalogları pratik yapıp. Bu noktada özdenetimini sağlayabilir." 
Öğrencilerin DynEd üzerinden çalışmalarının izlenmesini kapsayan öğrenci takibi kategorisinde başarı düzeyi, sistemde kalma, ilerleme ve raporlama ile eksiklikleri görme ve geri dönüt kodları oluşmuştur. Araştırmaya katılan 7'si öğrencilerin başarı düzeylerini DynEd üzerinden görebildiklerini, 7'si DynEd sisteminde kalınan süreyi, 7'si ilerleme ve raporlamaları, 3'ü ise eksiklikleri görme ve geri dönüt verebildiğini belirtmiştir. Bunlara ait bazı öğretmen görüşleri şu şekildedir.

- Ö1, “...kayıt yöneticisi ile yüzde kaç ilerlediklerini görebiliyoruz. DynEd üzerinden yüzde kaç girmiş, kaç, ne kadar durmuş. Sistem yeterince ses kaydı yapmıyorsun diyebiliyor, daha sık çalşmalısın, son haftalarda fazla girmemişsin gibi uyarılarda bulunarak çocuklar yönlendiriyor, eksiklerini tamamlamasına için yardimcl oluyor."

- Ö6, “...DynEd seviye tespit sinavı var. Herkesi farkh farkl bölümlerden başlatyyor. Kimisi en alt seviyeden kimisi daha üst seviyeden başlyor. Puanlama sistemi çok güzel. Çünkü öğrenci hangi seviyeye geldiğini görebiliyor."

- $\quad$ Ö7, "...şöyle her yaptı̆̆ına puan veriyor, sürekli kullanmasını istiyor. Aslında sistem güzel bir puanlama üzerine kurulmuş."

- Ö10, “...öğrencileri sistemden takip edebiliyoruz aylik raporlar şeklinde zaten biz alıp hem Milli Eğitim'e hem okula teslim ediyoruz. Adım adım, kaç saniye, ne kadar kaldı bunlarn görmek çok kolay. Bu raporları öğrencilerle de paylaşıyoruz dönüt olarak. ... seviyesine göre ilerledikçe başardıkça bir sonraki modül açılıyor. Bu bize öğrencinin gelişimini gösteriyor. Öğrenci yanlış yaptıkça sistem onu geri gönderiyor, doğruyu bulana kadar devam ediyor. Dolayısıyla eksik kalan öğrenmeyi de tamamlamıs oluyor. Bu noktada dönütler alabiliyoruz."

Öğrencilerin DynEd'in hangi özelliklerini en sık kullandıklarına dair dört adet kodlama yapılmıştır. Kelime çalışması 3, boşluk doldurma 3, test çözme ve gramer uygulamaları konusunda 1 öğretmen öğrencilerin sık kullandıklarını belirtmiştir. Ö6 ve Ö8, “...genelde kelime çalışıyorlar.” Ö5, “...işte kelimeleri belki oradan duyduğu kelimeler tanıdık geliyor, gördüğ̈̈ kelimeler." Ö10, “...kelime aşinalı̆̆ oluyor." Ö12, “...test çözmeyi en çok yapıyorlar.” Ö5, “...genelde test çözme kısmını kullanıyorlar.” Ö3, “...programa İlgi duyup kullanan çok az sayıdaki öğrencilerimizin en fazla kullandığı beceri alanı ise gramerdi.” Ö11, “... arka arkaya açllan soru gruplarn içinde sadece soru cevaplayıp boşluk doldurdular."

DynEd programı kullanım sorunları

DynEd kullanım aşamalarında yaşanan sorunlar teması altında donanım, cep telefonu, zaman, veli ve sorun çözümü olmak üzere 5 kategori ile bunlara 
ait kodlar oluşturulmuştur. Kategoriler ve altında yer alan kodlar Tablo 7'da verilmiştir.

Tablo 7. DynEd programının kullanımındaki sorunlar

\begin{tabular}{|c|c|c|c|}
\hline Kategori & Kodlar & & f \\
\hline \multirow[t]{3}{*}{ Donanım } & $\begin{array}{l}\text { Bilgisayar projeksiyon, Akıllı tahta, } \\
\text { kulaklık bulunmaması }\end{array}$ & Ö1,Ö2,Ö3,Ö4,Ö5,Ö6,Ö7,Ö8,Ö10 & 9 \\
\hline & Dil laboratuvarının bulunmaması & Ö1,Ö3,Ö4,Ö6,Ö7,Ö8,Ö10 & 7 \\
\hline & İnternet bağlantısı olmaması & Ö3,Ö4,Ö5,Ö6,Ö8 & 5 \\
\hline \multirow[t]{3}{*}{ Akillı telefon } & Yazllım yükleme & Ö2,Ö3,Ö5,Ö6,Ö11 & 5 \\
\hline & Akıllı telefon olmaması & Ö3,Ö4,Ö5 & 3 \\
\hline & Sürükle bırak işleminin zorluğu & Ö6 & 1 \\
\hline Zaman & Süre yetersizliği & Ö2,Ö4,Ö5,Ö6,Ö7,Ö10 & 6 \\
\hline Veli & İlgisi & Ö1,Ö3,Ö4,Ö5,Ö7,Ö8,Ö9,Ö10,Ö11,Ö12 & 10 \\
\hline Problem & İdare desteği & Ö1,Ö2,Ö6,Ö7,Ö8,Ö10 & 6 \\
\hline \multirow[t]{4}{*}{ çözümü } & Arkadaş desteği & Ö2,Ö3,Ö10,Ö11,Ö12 & 5 \\
\hline & Bilgisayar öğretmeni desteği & Ö1,Ö2,Ö10 & 3 \\
\hline & DynEd koordinatör desteği & Ö1,Ö2,Ö6 & 3 \\
\hline & Whatsup grubu & Ö6,Ö10 & 2 \\
\hline
\end{tabular}

DynEd kullanımında yaşanan problemlerin başında donanım sorunlarının yer aldığ1 görülmüştür. Donanım eksikliği olarak bilgisayar, projeksiyon, akıllı tahta ve kulaklık vb. cihazların bulunmadığını 9, dil laboratuvarının bulunmadığını 7 ve internet bağlantısının bulunmadığını ise 5 öğretmen belirtmiştir. Öğretmenlerin donanım ile ilgili görüşleri bazıları aşağıda verilmiştir. - Ö1, “....bilgisayar laboratuvarında ses, kulaklık olmadığ için teknik destek olmadığı için bilgisayar laboratuvarını hiç kullanamadık."

- Ö2, "....mikrofon ve kulaklik eksikti."

- Ö4, “....bilgisayar laboratuvarı falan yok.....ama dil laboratuvarları olsa bir de...."

- Ö5, “....smiflarda ya projeksiyon olmuyor, ya akllh tahta olmuyor."

- Ö6, “....işte sınıfta bilgisayarımız yok. Projeksiyon var...."

- Ö7, “....maalesef alt yapı olmadiğ için, akıll tahtalarımızda internet yok ....bunu bir tane akıllı tahta ile yapacă̆ım, bilgisayar odasına indireceğim, 15 tane bilgisayar yok."

DynEd akıllı telefon uygulaması üzerinden yaşanan problemlere ait üç kod oluşturulmuş olup bunlar; yazılım yüklenmesi, sürükle bırak işlemi ve akıllı telefona sahip olunmaması şeklinde kodlanmıştır. Bu kodlardan yazılım yükleme problemine ait 5 öğretmen, akıllı telefona sahip olunmamasına ait 3 öğretmen ve sürükle bırak işleminin zorluğuna ait bir öğretmen görüş 
bildirmiştir. Ö2, “....DynEd mobili çocukların telefonuna yüklemeye çalıştık. Apple telefonlarda problemler oldu, ipad falan tabletlerde problem oldu." Ö6, "....mobil uygulamayı kullanıyorlar ama dediğim gibi genelde o sürükleme kısmında sanırım, bana çünkü hep telefonda kullananlardan o sorun gelmişti.” Ö3, “....bu programı kullanmaları için gereken internet, akull telefon vs. gibi donanımlarmın eksikliğinden kaynaklı bir ilgisizlik söz konusu." Ö4, “.....işte, akıllı telefonu yoktur, evde tableti yoktur, pc'si yoktur. ....bazıları da akıllı telefonuma kurdum ama telefonum kaldırmadı diyenler var."

DynEd'in sınıf içerisinde kullanımına yönelik zamanın yeterli olmadığını öğretmenler belirtmiş olup zaman kategorisi süre yetersizliği kodu oluşturulmuş, bu koda dair 4 öğretmen görüş bildirmiştir. Ö6, “ ....ders saatleri yetersiz. Bence an az bir 10 saat olması lazım, çok ütopik bir durum belki ama. Esas sıkıntı zaman sıkıntısı.” Ö7, “...okulda pek tercih etmiyoruz çünkü müfredatı yetiştirme telaşı var." Ö10, "....sinıf içerisinde zaman yeterli olmuyor."

Öğrenci velilerinin DynEd hakkında ilgisine yönelik oluşturulan koda 10 öğretmen görüş bildirmiştir.

- Ö2, “....velilerimizin profili belli. Çoğu Kırsal Kesim. Öğrencisinin sinıfindan Haberi yok, numarasını geçtim. Şu anda velilerle bunu konuşmak ütopik bir durum."

- Ö3, “...DynEd uç bir şey veliler için, yok yani bilgileri. Destek alamıyoruz."

- Ö5, "...velilerin çoğu çocuklarm bilgisayarlarma kurdu. Veliler destek oldu. 5'lerde bunu sağlamamızın sebebi zaten velilerin desteğiydi."

- Ö6, "....veliler destek oluyor ama sanırım çok da farkında değiller."

- Ö7, "....veliler dyned konusunda biraz bilgisiz diyebiliriz. Illgili öğrencilerin velileri daha çok dynedin ne olduğunu biliyor."

- Ö10, “....bu noktada herhalde en habersiz olan kesim velilerdi. Velilerin dyned diye bir sistemden çoğunun haberinin olmadığın düşünüyorum varsa bile isim olarak kulaklarındadır ama içeriğinin ne olduğunu, çocuğuna ne kattıklarımı bildiklerini düşünmüyorum."

DynEd kurulumu ve kullanımında öğretmenler yaşanan problemlerin çözümünde en çok desteği kimlerden aldıklarına dair oluşturulan kodlar idare, arkadaş, bilgisayar öğretmeni, DynEd koordinatörü ve Whatsup grubu desteği olmak üzere toplam 5 kod adet oluşmuştur. Bu kodlara idare ile ilgili olarak 6 öğretmen, arkadaş desteği 5 öğretmen, bilgisayar öğretmeni ve DynEd koordinatörü desteği 3 öğretmen ve Whatsup desteği konusunda 2 öğretmen görüş bildirmiş̧ir. Bu görüşlerden bazıları aşağıda verilmiştir. 
- Ö1, “....bu seneki uygulamasinda yeterli desteği Koordinatör öğretmenimizden aldık. Neyi, nasıl yapacağımızı anlattı ve okuldaki bilgisayar öğretmenimiz sayesinde de bir şeyler yaptık."

- Ö2, “....okul İdaresi destek oldu. Özellikle de DynEd kullanımı için okula telefon getirilmesi, kurslarda kullamılabilmesi için gerekli desteği sağladı."

- Ö5, “....DynEd Whatsapp grubunda sorabileceğimiz kişiler vardı. Onlardan destek alabiliyoruz."

- Ö10, “....Whatsup grubu var ve orada koordinatör yönlendirmeler yapıyor."

DynEd'in İngilizce eğitiminde yaşanan problemlere ne derecede çözüm getireceği ve DynEd'in daha aktif kullanılmasına yönelik 2 kategori ve bunlara ait kodlar Tablo 8'de verilmiştir.

Tablo 8. DynEd'in İngilizce eğitimine katkısı ve etkili kullanımı

\begin{tabular}{llll}
\hline Kategori & Kodlar & f \\
\hline $\begin{array}{l}\text { Ingilizce } \\
\text { eğitimine } \\
\text { katkısı }\end{array}$ & DynEd İngilizce eğitim sorunlarını çözüm olmaz & Ö3,Ö4,Ö7,Ö9,Ö10,Ö11,Ö12 & 8 \\
\hline Destekleyici olur & Ö5,Ö6,Ö7,Ö8 & 4 \\
kullianım & Müfredata yönelik düzenleme & Ö6,Ö7 & 2 \\
& Öğrencinin ihtiyaç hissetmesi & Ö3 & 1 \\
& Kurulum basitleştirilmeli & Ö12 & 1 \\
& Alt yapı desteği sağlanmalı & Ö10 & 1 \\
& Öğrenci ve velilere tanıtım yapılmalı & Ö5 & 1 \\
\hline
\end{tabular}

DynEd'in İngilizce eğitimine katkısı kategorisinde 8 öğretmen “DynEd İngilizce eğitim sorunlarnı çözüm olmaz." görüşünü bildirirken, 4 öğretmen "destekleyici olur." şeklinde görüş bildirmiştir. Bu görüşlerin bazıları şu şekildedir. - Ö3, “....DynEd bu sorunlara çözüm olamaz"

- Ö4, “...DynEd bu sorunlara mümkün değil, çözüm olamaz."

- Ö5, "....eksikleri Dyned ile tamamladık desek yalan olur, dyned sadece destekleyici olacaktır."

- Ö6, "....tek başına Dyned sadece bir araç, iyi bir araç."

- Ö9, “....evet, konuşma, ben konuşmaya çok takıyorum maalesef. Evet yazma olabilir, dinleme evet dinleme de var. Ancak konuşmaya ă̆ırlı vermediği sürece bunun çok yürüyeceğini düşünmüyorum açıkçası."

- Ö10, “....kısmen olabilir, kısmen olabilir. Çünkü artık biliyorsunuz bir sürü şey var, yöntem var. Flip classroom bunlardan bir tanesi."

- Ö11, “....Dyned yabancı dil sorununa çözüm olamaz. Bunun için en iyi yol dil kampları." 
- Ö12, “.....Dyned tek başına yabancı dil eğitimindeki bu eksiklere yardımol olmaz."

- Ö3, “......̇ngilizce'nin eksikliğini hissetmeleri etmeleri lazım. Yani ihtiyaç olarak görmedikleri sürece öğrenmek istemeyecekler, öğrenmek istemedikleri şeyi de niye çalışsın?"

- Ö5, “....Çocuklara da veliye de dynedi güzel tanıtabilmek lazım."

- Ö6, "....biraz daha müfredata yönelik olabilir. Çünkü dyned müfredata yönelik değil."

- Ö7, “....Dyned programı yenilenirse, güncellenirse eğitim sistemindeki sorunlara çözüm olamaz ama programa yardımcı olabilir."

- Ö9, “.....Çok fazla konuşma üzerine olmadığından dolayı sorunlar oldŭ̆unu zaten söylemiştim. Dyned bu aşamada bu sorunlara çözüm olamaz."

- Ö10, “.....̈̈ncelikle alt yapmın düzeltilmesi gerektiğini düşünüyorum. Yani bu bütün okullara zorunlu olacaksa az önce de dediğim gibi bilgisayarn olmayan okullar var."

- Ö12, “...Önce kurulumun düzenlenmesi lazım, rahatlaması lazım ondan sonra. İ̧eriği güzel. Sonuçta listening, speaking koydularsa yeterlidir, güzeldir."

\section{Tartışma ve Sonuç}

Yapılan bu çalışma ile İngilizce dil eğitiminde yaşanan sorunların derinlemesine araştırılması, 2008 yılından itibaren eğitim sistemimizde uygulanan DynEd yazılımının İngilizce dil eğitimine katkısı, DynEd uygulaması esnasında yaşanan sorunlar ve bu sorunların giderilmesine yönelik öğretmenlerin görüşlerine başvurulmuştur.

Yıllardır yabancı dil eğitiminde yaşanan sorunların çözümü için eğitim programları, uygulanan eğitim politikalarında değişikliğe gidilerek sürekli yenilikler yapılmasına rağmen yabanc dil öğreniminde önemli sorunlar ile hala karşılaşılmaktadır (İşler ve Günbayı, 2017). Yabancı dilde yaşanan sorunlar ile ilgili 1983 yılında Türk Eğitim Derneği (TED) tarafından yapılan çalışmada sınıfların kalabalık olması, eğitim esnasında Türkçe konuşulması, sistem değişiklikleri, yabancı romanların okutulmaması, öğretmenlerin öğrencileri güdüleyemediklerinden bahsedilmekte ve çözüm olarak da teknolojiden yararlanılması gerektiği belirtilmektedir (TED, 1983). Yapılan çalışmada İngilizce dil eğitiminde yaşanan sorunlar hakkında öğretmenlerle ya- 
pılan görüşmelerin analizinde belirttikleri konular, ders saatlerinin yetersizliği, sınıf mevcutlarının fazla olması, sistem değişiklikleri ve İngilizce hazırlık sinıflarının olmamasını göstermektedirler. Aradan otuz beş yıldan daha fazla bir süre geçmesine rağmen TED'in yaptı̆̆ı çalışma ile araştırma bulguları aynen örtüşmektedir. Yine araştırma bulgularında okullarda bilgisayar, dil laboratuvarı, projeksiyon, akıllı tahta, kulaklık, mikrofon gibi donanım eksikliklerinin bulunduğunu, bunlarında teknoloji destekli eğitime engel olduğunu öğretmenler vurgulamaktadır. Araştırmada donanım eksikliklerinin ile birlikte dil eğitiminde problem olarak günlük hayatta kullanılmaması, telaffuz problemleri, gramer ağıllıklı eğitim, yazma uygulamalarının bulunmaması, müfredatın okullara uymaması, öğretmenlerin teknolojiye karşı gösterdikleri direnç ve öğrencilerin önbilgileri ile hazır bulunuşluk düzeylerinin yetersizliği gösterilmektedir. Araştırmada İngilizce dil eğitiminde yaşanan problemlerin çözümü için öğretmenler oyun tabanlı eğitim, konuşma ağırlıklı, okullara göre düzenlenen müfredat, ders saatlerinin artırılması teknoloji destekli materyallerin sınıf ortamlarında kullanılmasının gerekliliğini vurgulamaktadırlar. Kırkıç (2019) yabancı dil öğreniminde öğrencilerin karşılaştı̆̆1 en önemli sorun, dilbilgisi odaklı öğretmenler olduğunu belirtmiştir. Özellikle yabancı dil eğitiminde sıkıntılar yaşanan ve istenilen başarıya ulaşılamayan ülkemizde, dil öğretiminde verimi artırmak ve öğrencilere farklı olanaklar sunmak adına yabancı dil eğitim programlarının başta bilgisayar olmak üzere çeşitli bilişim teknolojileriyle desteklenmesi gerekmektedir (Kozikoğlu, 2013).

MEB yabancı dil eğitimine destek olması amacyyla DynEd İngilizce dil eğitim yazılımın 2008 yılından itibaren okullarda uygulamaya çalışmaktadır. Yeni teknolojileri kullanarak dil eğitiminde başarı elde edilmek amaçlanıyorsa, öncelikle öğretmenlerin buna inandırılmasına ihtiyaç vardır (Baki, 2001). Öğretmenin inanması kadar teknoloji konusunda yeterlikleri önem taşımaktadır. Araştırma bulgularında öğretmenlerin büyük bir çoğunluğu teknoloji kullanımı konusunda kendilerini yeterli görmekte iken, bir bölümü ise kendilerini yetersiz görmekte, yalnızca bir öğretmen kendisinin kısmen yeterli olduğu belirtmiştir. Öğrencilerin teknoloji kullanımı ile ilgili yeterliklerine öğretmenlerin tamamı öğrencilerin çok iyi düzeyde olduğunu belirtmiştir. Yine öğretmenlerin çoğu öğrencilerin DynEd'i çok kolay kullandıklarını belirtmelerine rağmen, öğrenciler için DynEd'in ilgi çekici olmadığı görüşündedirler. Araştırma bulgusunu destekler yönde, Meri (2012) birinci kademe 
öğrencileri ile yapmış olduğu çalışmada öğrencilerin \%66.6'sının öğretmen desteği olmadan DynEd'i kullandıklarını belirtmiştir. Bunda da öğrencilerin dijital çağda dünyaya gelmiş olmaları ve teknoloji ile içiçe büyümüş olmaları etkili olabilir. Teknoloji tabanlı BDE İngilizce eğitiminde öğrencilerin farkındalığı, öğrenmeye kaşı tutumları ve dijital okuryazarlık etkili olmaktadır (Lai ve $\mathrm{Gu}, 2011)$.

Öğretmenler DynEd yazılımının özelliklerini; telaffuz, dinleme, konuşma, yazma, ses kaydı, seviye sınavı, oyun özelliği, özdenetim olarak sıralamışlardır. Öğrencinin DynEd kullanımın takibi konusunda ise; başarı seviyelerini, sistemi kullanma sürelerini, ilerleme aşamalarını, raporlama ve öğrencinin eksikliklerini görebildiklerini belirtmektedirler. Öğrencilerin en sık kullandıkları özellikler olarak kelime çalışmaları, boşluk doldurma, test çözme ve gramer uygulamaları olduğunu tespit etmişlerdir.

DynEd yazılımının kullanılmasında donanım ile ilgili yaşanan problemler hakkında öğretmenler; bilgisayar, dil laboratuvarı, projeksiyon, akıllı tahta, kulaklık vb. donanımların bulunmaması aynı zamanda internet bağlantısının olmadığını belirtmişlerdir. İnternet bağlantısının olmaması dil eğitimini olumsuz etkilemektedir (Meena, 1997).

DynEd yazılımının akıllı telefonlarda kullanımı ile ilgili olarak; akıllı telefonların işletim sistemlerinden kaynaklı yüklenememe, sürükle bırak özelliklerinin kullanılmasında problemlerin yaşandığını araştırmada elde edilen bulgular arasındadır. DynEd sınıf içerisinde uygulama süresinin yetersiz olduğu, öğrenci velilerinin de ilgisiz olduğu elde edilen diğer bir bulgudur. DynEd kurulum ve sınıf içerisinde uygulamada yaşanan problemlerin çözümünde ise; bilişim öğretmenleri, DynEd koordinatörü ve deneyimli arkadaşlarından destek aldıkları görülmüştür.

Araştırma bulgusunda öğretmenlerin belirttiği problemler olarak öğrencilerin yabancı dile karşı ilgisizliği, ders saatlerinin yetersiz olması, altyapı ve donanım eksiklikleri, müfredatın okullara göre ayrı olması gerektiği, ders içeriklerini dile getirmişlerdir. Öğretmenlerin belirtmiş olduğu bu problemler İşler ve Günbayı (2017) öğretmenlerle yapmış oldukları çalışma ile örtüşmektedir.

Araştırmaya katılan öğretmenlerin büyük bir çoğunluğunun görüşü DynEd İngilizce dil eğitiminde yaşanan sorunlara çözüm olamayacağı görüşünde, bir kısmı da destekleyici olacağı yönünde görüş bildirmişlerdir. Öğ- 
retmenlerin en temel görevleri, öğrencilerin öğrenebilecekleri bir öğrenme ortamı hazırlamaktır. Öğrenciler kendilerini sözlü olarak ifade etmekte özgür ve rahat hissetmelidirler. Aksi takdirde, öğrencilerin İngilizce konuşma becerilerinin geliştirilmesi engellenecek ve dil öğrenme süreci sonuçsuz kalacaktır (Kırkıç, 2019). Bilgisayarların dil öğretiminde tercih edilmesinin nedenleri uygulamalı eğitim fırsatı, motivasyon, öğrenci başarısını artırması, daha fazla etkileşim, bireysel öğrenme, tek bir kaynağa bağımlı kalmadan öğrenme ve evrensel bakış açısı getirmesidir (Lee, 2000). Eğer öğretmen kullanacağı donanım ve yazılım hakkında yeterli bilgiye sahip değilse BDE başarılı olunması beklenmemelidir (Baki, 2001). Araştırmada öğretmenler yabancı dil eğitiminde yaşanan sorunları ders içeriklerinde günlük konuşma etkinlikleri, dinleme, telaffuz ve yazma etkinliklerinin olmaması olarak belirtmişlerdir. DynEd'in özellikleri hakkında ise telaffuz, dinleme, konuşma, yazma, ses kaydı, oyun tabanlı uygulamalarının yer aldığını belirtmelerine rağmen, DynEd'in İngilizce dil eğitimine çözüm olamayacağı görüşünü dile getirmişlerdir. Bu durum belirttikleri problemlerin aslında kendi ifadeleri ile DynEd içerisinde olduğunu göstermektedir. Bu durum öğretmenlerin kendi görüşlerinin birbiriyle çeliştiğini göstermektedir. Bunun nedeni okullarda teknolojik donanım (bilgisayar, akıllı tahta, mikrofon, kulaklık vb.) konusunda yeterli olmaması, dil laboratuvarlarının bulunmamasından kaynaklanıyor olabilir. Yada öğretmenler her ne kadar teknoloji kullanımı konusunda yeterli oldukları görüşünü belirtseler de bu durum teknolojinin eğitim uygulamalarında kullanılmaması, BDE konusunda yetersiz olmalarından kaynaklanıyor olabilir. Araştırmaya katılan öğretmenlerin büyük bir çoğunluğunun DynEd'in dil eğitimine katkısının olmayacağını düşünmesine rağmen Meri (2012) yapmış olduğu çalışmada öğrencilerin \%86.6'sının İngilizce öğrenimine katkı sağladığ 1 ve bilmedikleri kelimeleri öğrendiklerini ortaya koymuştur.

Yapılan çalışmada öğretmenler DynEd'in sınıf içerisinde uygulaması için ders saatlerinin yetersiz olduğunu belirtmişlerdir. Meri (2012) yapmış olduğu çalışmasında öğrencilerde DynEd için ayrılan sürenin yetersiz olduğunu belirtmektedir.

Yapılan bu çalışma on iki İngilizce öğretmeni, altı ortaokul ve altı lise ile sınırlı bir çalışmadır. Okulların teknolojik donanımları arasında farklar olduğu gibi, özellikle liselerin öğrenci profilleri ve başarı düzeyleri arasında da önemli farklar bulunmaktadır. Yapılacak diğer çalışmalarda teknolojik alt 
yapı ve öğrenci profilleri göz önünde bulundurularak başka çalışmalar yapılabilir. Öğretmenler kendilerini teknoloji kullanımında yeterli görmelerine rağmen teknolojinin pedagoji ile birlikte kullanılması konusunda yetersizlikleri olabilir. DynEd uygulanan okullarda İngilizce öğretmenlerine teknopedagojik eğitim konusunda hizmetiçi eğitimler verilebilir. 


\title{
EXTENDED ABSTRACT
}

\section{Opinions of English Teachers on Computer Based DynEd English Curriculum}

\author{
Bayram Gökbulut \\ Zonguldak Bülent Ecevit University
}

With the development of technology and globalization of the world, English has become the common communication language of countries. Many countries in the world provide English education to students starting from primary school. However, there are difficulties in English education in many countries. At the beginning of these difficulties, it is very important to develop students' listening, understanding and writing skills together. It can support students from computer-aided education in acquiring these skills to students. Many countries in the world use Dynamic and Education (DynEd), a computer-aided educational software.

In Turkey, the Ministry of Education has put English DynEd computer aided educational software applications in primary and secondary schools in 2008. DynEd English education software started to be implemented in high schools in 2014. Some problems arise during the implementation of the DynEd English education software implemented in primary, secondary and high schools. In order to make detailed determination of these problems, the opinions of English teachers were needed.

Teachers' opinions were needed to identify problems in English education and DynEd education.

English teachers were asked to answer the following questions:

- Do you find successful English language education in schools? Why is that?

- What do you think about the DynEd English language training program?

- What is its contribution to English language education?

- What are the problems in practice?

- How can DynEd be used more actively in class? 
Phenomenon science, one of the qualitative methods, was used in the research. Phenomenology is about the facts that we realize but do not have indepth insight on the subject.

In the research, maximum diversity sampling was used. Research Data were collected from 12 English teachers. 6 of these teachers work in secondary school and 6 in high school. 2 of the teachers are male and 10 are female.

The data were collected through a semi-structured interview form consisting of open-ended questions. Before the research, a pilot application was carried out with interview questions. In the study, the interviews lasted 11 minutes and the longest 35 minutes. The average interview time was 18 minutes. Before the interview, the teachers were informed about the purpose of the research and permission was obtained to record the interview. Themes and codes were created by using the content analysis method in the analysis of the data. The data were individually coded by two experts. The codes are divided into themes and subcategories. The codes determined by the experts were examined and the codes with consensus and disagreement were determined. Themes were checked by the expert and their validity was provided.

Problems in English language education;

They stated problems in English language education, less class hours, and excessive class sizes. Changing the education system very often affects English education negatively. As problems in language education, teachers see technological equipment (Computer, language laboratory, projection, smart board, headset etc.) deficiencies.

Problems in language education arise from the language not being used in daily life, and the inadequacy of listening, speaking, writing and telephony practices. It is emphasized that the curriculum should be different than the schools.

Teachers' views on DynEd software; They listed as pronunciation, listening, speaking, writing, sound recording, level exam, game feature, self-control.

As for the monitoring of the student's use of DynEd; They state that they can see their level of success, the times of using the system, their progress, reporting and student's shortcomings. They determined that vocabulary studies, filling in spaces, solving tests and grammar applications were the most frequently used features of students. 
There are problems with hardware when using DynEd software. These problems arise from hardware such as computer, language lab, projection, smart board, headset. There are also problems with the internet connection.

DynEd software has problems with drag and drop features on smartphones. The implementation time in DynEd class is insufficient. Student parents are not interested in DynEd. Teachers receive support from IT teachers and DynEd coordinator in DynEd setup and classroom applications.

The teachers state that the students are not interested in the foreign language. Course hours are insufficient for DynEd application. DynEd software is not compatible with the school curriculum. There are problems arising from infrastructure and hardware.

The vast majority of teachers state that DynEd cannot solve the problems experienced in English language education. It states that some teachers will support English education. In the study, teachers stated that the lesson hours were insufficient for the implementation of DynEd in the classroom.

\section{Kaynakça / References}

Baek, Y. K. (2008). What hinders teachers in using computer and video games in the classroom? Exploring factors inhibiting the uptake of computer and video games. CyberPsychology \& Behavior, 11(6), 665-671.

Baki, A. (2001). Bilişim Teknolojisi 1şı̆̆ı altında matematik eğitiminin değerlendirilmesi. Milli Ĕ̆itim Dergisi, 149, 26-31.

Başkale, H. (2016). Nitel araştırmalarda geçerlik, güvenirlik ve örneklem büyüklüğünün belirlenmesi. Dokuz Eylül Üniversitesi Hemşirelik Fakültesi Elektronik Dergisi, 9(1), 23-28.

Butler, G. Y. (2009). Teaching English to young learners: The influence of global and local factor. J. Enever, J. Moon \& U. Raman (Eds.), Young Learner English Language Policy and Implementation: International Perspectives içinde (s. 23-29). Reading: Garnet Education.

Büyüköztürk, Ş., Akgün, Ö.E., Demirel, F., Karadeniz, Ş. ve Kılıç Çakmak, E. (2012). Bilimsel araştırma yöntemleri. (Geliştirilmiş 12. Baskl). Pegem Akademi: Ankara.

Coşkun, P. E. (2013). Bilgisayar destekli DynEd programının ilköğretim İngilizce dersini desteklemesi hakkındaki öğretmen görüşleri: Kırşehir ili örneği. Yayınlanmamış Yüksek Lisans Tezi, Ahi Evran Üniversitesi, Sosyal Bilimleri Enstitüsü, Kırşehir. 
Çakmak, B. (2012). Appraising DynEd: A study into the teaching of language skills and technical features. Master's thesis. İstanbul University Institute of Social Sciences Department of foreign Language Teaching, İstanbul.

Enever, J. ve Moon, J. (2009). New global contexts for teaching Primary ELT: Change and challenge. J. Enever, J. Moon \& U. Raman (Eds.), Young Learner English Language Policy and Implementation: International Perspectives (s. 5-21). Reading: Garnet Education

Gündüz, N. (2005). Computer assisted language learning. Dil ve Dilbilimi Çalışmaları Dergisi, 1(2), 193-214.

İşler, S. ve Günbayı, İ. (2017). Orta öğretim yabancı dil program değişikliklerine ilişkin öğretmen görüşleri: Bir durum çalışması. Eğitim ve Öğretim Araştırmalarn Dergisi, 6(2), 34, 2146-9199.

Kaplan, A., Öztürk, M., Altaylı, D., ve Ertör, E. (2013). Sınıf öğretmenlerinin bilgisayar destekli öğretime yönelik tutumlarının bazı değişkenlere göre karşılaştırılması. Turkish Journal of Computer and Mathematics Education, 4(2).

Kırkıç, K. A. (2019). The effect of an innovative teaching technique on the success and attitudes of sixth grade english language students. Educational Research and Reviews, 14(7), 254-261.

Kozikoğlu, A. G. İ. (2013). Yabancı dil öğretiminde bilgisayar kullanımına ilişkin öğretim elemanlarının görüşleri. Yüzüncü Yıl Üniversitesi Ĕ̆itim Fakültesi Dergisi, 10(1), 373-394.

Lai, C. ve Gu, M. (2011): Self-regulated out-of-class language learning with technology. Computer Assisted Language Learning, 24:4, 317-335

Lee, K. W. (2000). English teachers' barriers to the use of computer-assisted language learning. The Internet TESL Journal, 6(12), 1-8.

Meena, S. (1997). The internet and foreign language education: Benefits and challenges. The Internet TESL Journal, 3(6), xxx-xxx.

Meri, S. (2011). Autonomous computer-assisted language learning: Turkish primary school students' perception of DynEd software. Master's thesis, School of Law, Arts and Social Sciences School of Humanities, University of Southamton. U.K.

Meri, S. (2012). Autonomous computer-assisted language learning: Turkish Primary school students' perceptions of dyned software. In International Conference "ICT For Language Learning".

Mete, H. C. (2010). Uzaktan İngilizce öğretiminde öğrenen özerkliğinin DynEd bă̆lamında ölçülmesi. Yayınlanmamış Doktora Tezi, İstanbul Üniversitesi, Sosyal Bilimleri Enstitüsü, İstanbul. 
Miles, M. B. ve Huberman, A. M. (1994). Qualitative data analysis. Thousand Oaks, CA: Sage.

Milli Eğitim Bakanlığı [MEB] (2017a). 2023 Eğitim Vizyon Belgesi.

Milli Eğitim Bakanlığı [MEB] (2017b). Resmi Örgün Okulları DynEd İngilizce Dil Ĕ̆itimi Kullanım Klavuzu.

Milli Eğitim Bakanlığı [MEB] (2019). DynEd bilgisayar destekli yabancı dil öğretim sistemi, 12.12.2019 tarihinde, https:/gaziantep.meb.gov.tr/www/dyned-bilgisayar-destekli-yabanci-dil-ogretim-sistemi/icerik/1381 adresinden erişilmiştir.

Önal, F. (2015). DynEd yazllımının öğrencilerin başarısına, bilişsel yükleme düzeylerine etkisinin ve tasarm açısından uygunluğunun incelenmesi. Yayınlanmamış Yüksek Lisans Tezi, Gazi Üniversitesi, Eğitim Bilimleri Enstitüsü, Ankara.

Saban, A. (2008). Okula ilişkin metaforlar. Kuram ve uygulamada eğitim yönetimi, 55(55), 459-496.

Sarıcaoğlu, A. (2010). The use of the international computer-assisted language learning program "Dynamic English"(DynEd) in primary schools in Turkey. Master's Thesis, Hacettepe University Graduate School of Social Sciences, Ankara.

Selçuk, E. H. (2016). DynEd eğitim yazılımının yabancı dil öğretiminde akademik başarıya etkisinin incelenmesi. Yayınlanmamış Yüksek Lisans Tezi, Adıyaman Üniversitesi, Sosyal Bilimleri Enstitüsü, Adıyaman.

Şengel, E., Öncü, S., ve Göktalay, Ş. B. (2014). Achievement in language learning: Effects of various computer assisted activities and computer literacy. $\mathrm{Ha}$ cettepe Üniversitesi Ĕ̆itim Fakültesi Dergisi, 29(29-1), 267-279.

Tafazoli, D. ve Golshan, N. (2014).Review of computer-assisted language learning: History, merits \& barriers. International Journal of Language and Linguistics, 2(5-1), 32-38.

Talim Terbiye Kurulu Başkanlığı (2017). Müfredatta yenileme ve değişiklik çalışmalarımız. Ankara.

TED (1983). Yabancı dil öğretimi ve sorunları. Türk Eğitim Derneği Bilimsel Toplantısı, Ankara

Türnüklü, A. (2000). Eğitimbilim araştırmalarında etkin olarak kullanılabilecek nitel bir araştırma tekniği: Görüşme. Kuram ve Uygulamada Ĕ̆itim Yönetimi Dergisi, 24(24), 543-559.

Ucur, A. (2010). DynEd programının uygulanabilme etkililiği hakkında öğrenci görüşleri:Safranbolu örneği. Yayınlanmamış Yüksek Lisans Tezi, Sakarya Üniversitesi, Sosyal Bilimleri Enstitüsü, Eğitim Bilimleri Dalı, Sakarya. 
Uras, K. S. (2018). DynEd mobil yazılımının ortaöğretim öğrencilerinin İngilizce dersi akademik başarılarına etkisi. Yayınlanmamış Yüksek Lisans Tezi, Ege Üniversitesi, Fen Bilimleri Enstitüsü, İzmir.

Yıldırım, A. ve Şimşek, H. (2011). Nitel araştırma yöntemleri. (8. Baskı). Ankara: Seçkin Yayıncılık.

Yiğit, M. A. (2010). Teachers' attitudes towards the "DynEd"in primary education in Turkey: From the 4th to 8th grades. Yayınlanmamış Yüksek Lisans Tezi, Karadeniz Teknik Üniversitesi, Sosyal Bilimleri Enstitüsü, Trabzon.

\section{Kaynakça Bilgisi / Citation Information}

Gökbulut, B. (2020). İngilizce öğretmenlerinin bilgisayar destekli DynEd İngilizce öğretim yazılımı hakkındaki görüşleri. OPUS-Uluslararası Toplum Araştırmaları Dergisi, 15(26), 4134-4165. DOI: 10.26466/opus.670073 